the "flexible doors" of the birth canal to a better incarnation, a "transfer" and a "promotion" to a more perfect state of being.

The birth imagery here picks up a submerged idea in Section 38 as well, in which the poet refers to his "crucifixion and bloody crowning." Jesus's crowning with thorns preceded his crucifixion. Whitman reverses the order because he wishes to allude to the "bloody crowning" of his new birth as well as his identification with Jesus's sufferings.

Both of the French words in "Song of Myself" intensify Whitman's simultaneous opposition and conflation of life and death. The concept is fully mystical, one of Whitman's major themes in all his poetry. In the passages of "Song of Myself" just examined, Whitman sees himself as messianic in his leadership of humanity into a new age. His use of French in those passages proves him Adamic in his creative control of language. As a logical extension of his organic theory of words, Whitman boldly appropriates into English from French two words which compress and enrich his meaning. In his use of foreign words as well as English, Whitman is a follower of Emerson, who urged the poet to mine language wherever he finds it, minting and bringing new words into the currency of the American vernacular. This is not to suggest that Whitman is universally successful in achieving his intentions in the use of foreign words in his poetry - usually he is not-but perhaps some of those words deserve a second look.

Gustavus Adolphus College

DOUGLAS LeONARD

\title{
NOTES
}

1 Louise Pound, "Walt Whitman and the French Language," American Speech, 1 (May 1926), 421.

2 Pound, p. 423.

3 Gay Wilson Allen, The New Walt Whitman Handbook (New York: New York University Press, 1975), p. 243.

4 Roger Asselineau, The Evolution of Walt Whitman (Cambridge: Harvard University Press, 1962), 2:236.

5 Le Robert Dictionnaire Alphabétique et Analoguique de la Lingua Française (Paris: Société du Nouveau Littré Le Robert, 1973).

\section{THE ENDING OF THE 1855 VERSION OF "SONG OF MYSELF"}

There has been much comment on Whitman's verse structure in Leaves of Grass. Chiefly he focused on the biblical principle of parallelism, where the line is the unit, with the second line either balancing the first, "completing or supplementing its meaning." 1 Put another way, "The law of his structure is that the unit of sense is the measure of the line. The lines, in sense, are end-stopped. Whitman employed everywhere a system of punctuation to indicate his structure. Look down any page of Leaves of Grass, and you will find almost every line ending in a comma; you will find a period at the end of a group of lines or a whole poem." In short, "a run-on line is rare in Whitman-so rare that it may be considered 'a slip."'2 
In the first (1855) edition of Leaves of Grass, the omission of terminal punctuation for the final line of the then untitled first poem, later "Song of Myself," has occasioned critical comment. The final stanza of the 1855 version of "Song of Myself" reads:

\author{
Failing to fetch me at first keep encouraged, \\ Missing me one place search another, \\ I stop some where waiting for you $^{3}$
}

One writer, Jon Bracker, feels that "the last line of Whitman's poem lends itself to the omission of punctuation at the end.... Is it not possible that Whitman wanted to reinforce the idea that until the reader catches up with the poet, the poem is incomplete?"4 And without comment Malcolm Cowley let stand the omission of terminal punctuation in the final line of "Song of Myself" in his reprint of The First (1855) Edition of Leaves of Grass (New York: Viking, 1959), p. 86. We learn why from a letter he wrote Bracker: "I agree with your wild surmise-I think the omission of a period in the first edition was deliberate-I think it was intended to imply that the life and action of the poem were continuous, the vision repeating itself over the ages." 5

However, an examination of Whitman's corrections for the 1855 text of "Song of Myself" would support the position that this omission was not by design, but was a typographical error which he caught along with most of the other errors in the next (1856) edition. (Elsewhere Cowley silently followed these other corrections.)

The first edition of Leaves of Grass, a thin quarto of ninety-five pages, was printed in 795 copies by the Rome Brothers in Brooklyn. ${ }^{6}$ Whitman, an experienced printer, had set a few pages of type for the first edition, and corrected proof at the printer's for a few hours each day. ${ }^{7}$ One must wonder whether he was around to see that his corrections were honored, given the number of typographical errors that appear in the forty-four page "Song of Myself." For example, "Echoes" read "Echos" (on the first page), "adobe" and "canvas" read "abode" and "canvass" (in the same line), "development" read "developement," "chef-d'oeuvre" read "chef-d'ouvre," "conical firs" read "conical furs," "an armed force" read "am armed force," and "omnivorous" read "omniverous." There was also an error in the final stanza, two lines above the disputed final line. "Failing to fetch me at first keep encouraged," read "fetch me me at first."

As it happens there is another instance in the 1855 "Song of Myself" where terminal punctuation is missing from the final line of the stanza. This occurs 120 lines from the end of the poem. These are the only two lines in the entire 1855 edition lacking terminal punctuation.

Long enough have you dreamed contemptible dreams,

Now I wash the gum from your eyes,

You must habit yourself to the dazzle of the light

and of every moment of your life ${ }^{9}$

Cowley silently added a terminal period following "life" (p. 81). Following his reasoning on the final line of the poem, this line as well could easily conform to the idea of a continuous, repeating vision. Cowley seems to want it both ways. The omission of one terminal period is a typographical error; the other is by design. ${ }^{10}$ If Whit- 
man had intended to convey the idea of recurrence in the 1855 "Song of Myself" by omitting the final period, surely it would seem reasonable to assume that his great emphasis in Leaves of Grass on the bond of comradeship would have led him to retain this ending for the poem in at least one, if not all, of the other five editions. ${ }^{11}$

The fact remains that Whitman corrected all but three of the 1855 errors in "Song of Myself" in 1856. He also added terminal periods following "life" and to the final line of the poem and retained these corrections in all later editions. Despite the fanciful critical flights the omission of the final terminal period in "Song of Myself" has occasioned, the overall evidence would support reading the omission simply as a typographical error.

ARTHUR Golden

\section{NOTES}

1 J. H. Gardiner, The Bible as English Literature (New York: Scribner's, 1906), p. 107, quoted in Gay Wilson Allen, The New Walt Whitman Handbook (New York: New York University Press, 1975), p. 216; see also pp. 215-218 and Allen's essays "Biblical Analogies for Walt Whitman's Prosody," Revue Anglo-Américaine, 10 (August 1933), 490-507, and "Walt Whitman," American Prosody (New York: American Book Co., 1935), pp. 217-242.

2 E. C. Ross, "Whitman's Verse," Modern Language Notes, 45 (June 1930), 363-364, quoted in Allen, pp. 218-219. Also Autrey Nell Wiley, "Reiterative Devices in 'Leaves of Grass,", American Literature, 1 (May 1929), 161, quoted in Allen, p. 347, 32n, supports this view: "In more than 10,500 lines in Leaves of Grass, there are, by my count, only twenty run-on lines."

3 Leaves of Grass: A Textual Variorum of the Printed Poems, 1855-1856, ed. Sculley Bradley, Harold W. Blodgett, Arthur Golden, and William White (New York: New York University Press, 1980), 1:83, 11. 1344-1346. (All subsequent references to the Variorum are to this volume.)

4 Jon Bracker, "The Conclusion of 'Song of Myself,' Walt Whitman Review, 10 (March 1964), 21-22.

5 Bracker, 22. Michael Orth, "Walt Whitman, Metaphysical Teapot: The Structure of 'Song of Myself," Walt Whitman Review, 14 (March 1968), cited Bracker and accepted without question his and Cowley's assumptions on the ending of "Song of Myself": "It is perhaps significant that in 1855 , before Whitman began his many concessions to convention, the text provided no period at the end of 'Song of Myself.' The action does not stop, it continues" (24). Richard Bridgman, ed., Leaves of Grass by Walt Whitman: A Facsimile of the First Edition (San Francisco: Chandler Publishing Co., 1968), also accepts as fact that the omission of the final period in "Song of Myself" was by design: "It is an apt conclusion, in that, formally, it does not conclude. Quite as open-ended as Whitman conceived man's possibilities to be, the last sentence has no period" (p. xxxix). Although Ivan Marki, The Trial of the Poet: An Interpretation of the First Edition of Leaves of Grass (New York: Columbia University Press, 1976), sees the omission of the terminal period as "most likely an accident, ... probably a typographical error," in a curiously argued passage he feels that it is "not the less effective for that ... it allows the last words to reverberate and then die slowly away, so that they all but beckon the listener on. ..." For this reason, he finds that Bracker (and by inference Cowley) has "speculated very persuasively that Whitman omitted the punctuation mark on purpose ..." (pp. 186-187). Whatever Marki's initial ideas on the subject, he clearly finds this argument attractive and soon appears to reverse himself on the ending of "Song of Myself": "the poet's voice is heard again [in the next poem] after it trailed off in the unpunctuated farewell concluding his celebration of himself..." (p. 231). 
6 See Charles E. Feinberg, "Notes on Whitman Collections and Collectors," Walt Whitman: A Catalog Based Upon the Collections of the Library of Congress, compiled by Harold W. Blodgett and Henry J. Dubester (Washington, D. C.: Library of Congress, 1955), pp. xi-xii, and Leaves of Grass By Walt Whitman: Reproduced from the First Edition (1855) [The Facsimile Text Society], ed. Clifton J. Furness (New York: Columbia University Press, 1939), p. v. We get no help on the question of the ending of "Song of Myself" from the manuscript of the first edition. It was held for several years by the Rome Brothers and then accidently destroyed. See Horace Traubel, With Walt Whitman in Camden (Boston: Small Maynard and Co., 1906), 1:92. One known leaf has survived, in the Feinberg Collection, Library of Congress (Variorum, 15-16, 11. 245-267), reproduced in John C. Broderick, "The Greatest Whitman Collector [Charles E. Feinberg] and the Greatest Whitman Collection," Quarterly fournal of the Library of Congress, 27 (April 1970), [116]. I have seen several fragments in various collections, but none for the last line of the 1855 "Song of Myself."

7 Traubel, With Walt Whitman in Camden (New York: D. Appleton and Co., 1908), 2:471, and Gay Wilson Allen, The Solitary Singer (1955; rev. University of Chicago Press, 1985), p. 148.

8 Variorum, 2, 1. 22; 20, 1. 323; 27, 1. 430; 41, 1. 665; 47, 1. 772; 63, 1. 1015; 67, 1. 1084; 83, 1. 1344. Several of these errors continued into the 1856 edition, namely "canvass," "chef-d'ouvre," and "omniverous" (to 1860). In this connection, it might also be of interest to note that in "A Song for Occupations," which follows "Song of Myself" in the first edition, there is a glaring typographical error in line 30 of the poem. In "I own publicly who you are, if nobody else owns. ... and see and hear you, and what you give and take;" the "n" of the first "and" is reversed, to read "aud." This was corrected in 1856. See Variorum, 86, 1. 30.

9 Variorum, 76, 11. 1228-1230.

10 Three other editors who have reprinted the 1855 version of "Song of Myself" differed in part from Cowley in their approaches to the text. Gay Wilson Allen and Charles T. Davis, Whitman's Poems: Selections with Critical Aids (New York: New York University Press, 1955), retained "echos," "abode," "canvass," "developement," "chef-d'ouvre," "furs," and the final line. They silently corrected the others, adding a terminal period following "life." James E. Miller, Jr., Whitman's "Song of Myself"-Origin, Growth, Meaning (New York: Dodd, Mead, 1964), retained "abode," "canvass," "developement," and "furs." He silently corrected the others, adding a terminal period following "life" and bracketing a final terminal period to indicate its omission. Edwin H. Miller, Leaves of Grass: Selections (Northbrook, Ill.: AHM Publishing Co., 1970), silently corrected the errors in "Song of Myself," adding a terminal period following "life." He let the final line stand, with a note questioning whether the omission of the terminal period was accidental, or "intended, as recently suggested, to indicate eternal recurrence" (p. 84).

11 Variorum, 83, 1. 1346. 